\title{
ANALISIS DERAJAT KESEHATAN MASYARAKAT PROVINSI BALI DENGAN MENGGUNAKAN METODE GENERALIZED STRUCTURED COMPONENT ANALYSIS (GSCA)
}

\author{
Putu Nopita Purnama Ningsih ${ }^{1}$, Ketut Jayanegara ${ }^{2}$, \\ I Putu Eka Nila Kencana ${ }^{3}$ \\ ${ }^{1,2,3}$ Jurusan Matematika FMIPA Universitas Udayana, Bukit Jimbaran-Bali \\ e-mail: 1nopit14@gmail.com , ${ }^{2}$ ketut_jayanegara@yahoo.com, ${ }^{3}$ i.putu.enk@gmail.com
}

\begin{abstract}
The aim of this research is to determine the relationship between environmental, behavioral, health services, education, and economic variables to health status in the Province of Bali. These variables are constructs (latents) that can not be measured directly by observation. If there was a relationship between latent and its indicators, it is recomended to use Structural Equation Modeling (SEM). In this research we used variance-based SEM i.e. Generalized Structured Component Analysis (GSCA). This method not based on many assumptions such as the data does not have a multivariate normal distribution, the sample size does is not necessary large. Moreover, GSCA provides by overall goodness-fit of the model. The result of this research indicates that the environmental, behavioral, economic and educational variable influenced health status, but health service does not significantly affect the health status; economic does not significantly affect the environment; and education does not significantly affect the behavior. The result of the FIT value 0.450 and the AFIT value 0.429 showed that overall model in this research is not good enough because of both of these values are under 0.50 .
\end{abstract}

Keywords : Latent Variable, Structural Equation Modeling (SEM), Generalized Structured Component Analysis (GSCA), Derajat Kesehatan

\section{Pendahuluan}

Derajat kesehatan merupakan sebuah konsep yang menurut Hendrik L. Blum dalam Effendy[1] dipengaruhi oleh empat faktor, yaitu: lingkungan, prilaku, pelayanan kesehatan, dan genetik. Untuk meningkatkan derajat kesehatan, faktorfaktor tersebut harus dikendalikan dengan baik. Namun, faktor-faktor tersebut merupakan sebuah konstrak (latent/construct) yang hanya bisa diukur secara tidak langsung melalui pengamatan pada variabel observasi (observation/item variable). Pada saat hubungan antarvariabel yang terbentuk merupakan hubungan antarvariabel laten, maka metode yang dapat digunakan adalah Structural

\footnotetext{
${ }^{1}$ Mahasiswa Jurusan Matematika FMIPA Universitas Udayana

${ }^{2,3}$ Staf Pengajar Jurusan Matematika FMIPA Universitas Udayana
} 
Equation Modeling (SEM). Terdapat SEM berbasis kovarians dan SEM berbasis varians atau komponen. Generalized Structured Component Analysis (GSCA) merupakan SEM berbasis varians. SEM berbasis varians merupakan soft modeling yang tidak didasari asumsi berdistribusi normal, jumlah data tidak harus besar. Selain itu, dapat menganalisis secara bersamaan indikator dengan bentuk reflektif dan formatif [2]. Generalized Structured Component Analysis (GSCA) yang diusulkan oleh Hwang and Takane dapat mengatasi kelemahan Partial Least Squares (PLS) yang tidak menyediakan criteria global least square optimization yang dilengkapi dengan ukuran goodness-fit model secara keseluruhan [3] karena GSCA memiliki criteria global least square optimization, yang dapat secara konsisten meminimumkan sum squares residual untuk memperoleh estimasi parameter model.

Derajat kesehatan sangat penting dalam menggambarkan profil kesehatan masyarakat di suatu daerah. Dalam menilai derajat kesehatan masyarakat, digunakan indikator Angka Kematian Bayi (AKB) dan Angka Kematian Ibu (AKI). Faktor-faktor yang memengaruhi derajat kesehatan masyarakat tidak hanya berasal dari sektor kesehatan melainkan juga dipengaruhi oleh faktor ekonomi, pendidikan, lingkungan sosial, keturunan, dan faktor lainnya [4]. Rumusan masalah adalah bagaimana hubungan antara variabel lingkungan, perilaku, pelayanan kesehatan, pendidikan dan ekonomi terhadap derajat kesehatan masyarakat di Provinsi Bali dengan metode Generalized Structured Component Analysis (GSCA). Penelitian ini bertujuan untuk mengetahui hubungan antara variabel lingkungan, perilaku, pelayanan kesehatan, pendidikan, dan ekonomi terhadap derajat kesehatan masyarakat di Provinsi Bali dengan metode Generalized Structured Component Analysis (GSCA).

\section{Metode Penelitian}

Data dalam penelitian ini adalah data sekunder yang diperoleh dari Dinas Kesehatan dan Badan Pusat Statistik (BPS) Provinsi Bali untuk tiap kecamatan di Provinsi Bali sebanyak 57 kecamatan.

Variabel penelitian ini, yaitu: variabel laten ekonomi indikatornya jumlah penduduk yang bekerja pada sektor pertanian $\left(\mathrm{X}_{1}\right)$, jumlah penduduk 15 tahun ke atas yang bekerja $\left(\mathrm{X}_{2}\right)$, dan jumlah anggota $\mathrm{KUD}\left(\mathrm{X}_{3}\right)$. Pendidikan, indikatornya persentase penduduk berumur 10 tahun ke atas yang melek huruf $\left(\mathrm{X}_{4}\right)$, jumlah murid SD dan SMP $\left(\mathrm{X}_{5}\right)$, jumlah penduduk yang lulus sarjana $\left(\mathrm{X}_{6}\right)$. Pelayanan kesehatan, indikatornya persentase bayi yang diimunisasi campak $\left(\mathrm{X}_{7}\right)$, persentase persalinan ditolong oleh tenaga medis $\left(\mathrm{X}_{8}\right)$, persentase ibu nifas mendapat Vit $\mathrm{A}$ $\left(\mathrm{X}_{9}\right)$. Lingkungan, indikatornya persentase rumah sehat $\left(\mathrm{Y}_{1}\right)$, persentase keluarga memiliki jamban $\left(\mathrm{Y}_{2}\right)$, persentase keluarga dengan sumber air minum terlindung $\left(\mathrm{Y}_{3}\right)$. Perilaku, indikatornya persentase keluarga yang berperilaku hidup bersih (PHBS) $\left(\mathrm{Y}_{4}\right)$, persentase bayi diberi ASI eksklusif $\left(\mathrm{Y}_{5}\right)$, persentase posyandu aktif $\left(\mathrm{Y}_{6}\right)$, persentase masyarakat miskin berobat pada tenaga kesehatan (puskesmas) $\left(\mathrm{Y}_{7}\right)$. Derajat Kesehatan, indikatornya, angka kematian bayi (AKB) per 1000 
kelahiran hidup $\left(\mathrm{Y}_{8}\right)$, jumlah kasus penyakit TB Paru $\left(\mathrm{Y}_{9}\right)$, persentase balita gizi buruk $\left(\mathrm{Y}_{10}\right)$, angka kematian ibu (AKI) per 100000 kelahiran hidup ( $\left.\mathrm{Y}_{11}\right)$.

Adapun langkah-langkah untuk analisis data dengan metode Generalized Structured Component Analysis (GSCA), sebagai berikut:

1. Spesifikasi model.

2. Mengestimasi parameter menggunakan software open source GeSCA.

3. Mengevalusi model pengukuran dengan melihat signifikansi, menguji validitas dan reliabilitas menggunakan Average Variance Extracted (AVE) dengan AVE > 0.50 [5] dan Composite Reliability ( $\rho$ c) dengan nilai $\rho \mathrm{c} \geq 0.6$.

4. Mengevaluasi model struktural menggunakan koefisien determinasi $\left(\mathrm{R}^{2}\right)$ dan signifikansi koefisien jalur strukturalnya dilihat dari nilai CR (critical ratio) setara t-statistik melalui tahap bootstraping.

5. Evaluasi overall goodness fit model.

6. Membuat kesimpulan.

\section{Hasil dan Pembahasan}

Angka Kematian Bayi (AKB) terendah terdapat di Kecamatan Pupuan dan Kuta Utara dengan tidak ditemukannya kematian bayi. AKB tertinggi terdapat di Kecamatan Bangli sebesar 20 per 1000 kelahiran hidup. Jumlah kasus penyakit TB Paru terendah di Kecamatan Busungbiu, Selemadeg Timur dan Petang sebanyak 2 kasus sedangkan yang tertinggi di Kecamatan Denpasar Utara sebanyak 79 kasus. Persentase balita gizi buruk terendah terdapat di 20 Kecamatan dengan tidak ditemukannya balita gizi buruk di daerah tersebut dan tertinggi di Kecamatan Jembrana sebesar 1,90\%. Angka Kematian Ibu (AKI) terendah terdapat di 25 Kecamatan dengan tidak ditemukannya kematian ibu dan yang tertinggi di Kecamatan Pekutatan sebesar 70 per 100.000 kelahiran hidup.

Hasil evalusi model pengukuran menunjukkan bahwa indikator $X_{1}, X_{2}, X_{5}$, $X_{6}, X_{7}, X_{8}, X_{9}, Y_{1}, Y_{2}, Y_{3}, Y_{6}, Y_{7}, Y_{8}, Y_{9}$ berpengaruh terhadap variabel laten masing-masing, dengan nilai $\sqrt{A V E}$ lebih besar dari 0,5 dan composite reliability ( $\rho c)$ di atas 0,7 maka indikator dikatakan valid dan reliabel dalam mengukur variabel latennya. Dilanjutkan dengan evaluasi model struktural.

Tabel 1. Estimasi Parameter pada Model Struktural

\begin{tabular}{|l|c|c|c|}
\hline Hubungan variabel & Estimate & SE & CR \\
\hline Korelasi Ekonomi dengan Pendidikan & 0,674 & 0,101 & $6,66^{*}$ \\
\hline Ekonomi $\longrightarrow$ Lingkungan & 0,110 & 0,143 & 0,77 \\
\hline Ekonomi $\longrightarrow$ Derajat Kesehatan & $-0,351$ & 0,140 & $2,51^{*}$ \\
\hline Pendidikan $\longrightarrow$ Perilaku & $-0,029$ & 0,153 & 0,19 \\
\hline Pendidikan $\longrightarrow$ Derajat Kesehatan & $-0,321$ & 0,140 & $2,29^{*}$ \\
\hline Pelayanan Kesehatan $\longrightarrow$ Derajat Kesehatan & $-0,176$ & 0,144 & 1,22 \\
\hline Lingkungan $\longrightarrow$ Derajat Kesehatan & $-0,217$ & 0,104 & $2,09^{*}$ \\
\hline Perilaku $\longrightarrow$ Derajat Kesehatan & 0,305 & 0,117 & $2,6^{*}$ \\
\hline
\end{tabular}

$\mathrm{CR}^{*}=$ signifikan pada taraf nyata 0,05 . Dikatakan signifikan pada $\alpha=0,05$ jika nilai t-

statistik( critical ratio $)>\mathrm{t}_{0,025 ; 56}=2$. 
Diperoleh nilai $\mathrm{R}^{2}$ untuk variabel derajat kesehatan sebesar 0,679, artinya keragaman derajat kesehatan dapat dijelaskan oleh variabel laten ekonomi, pendidikan, lingkungan, perilaku dan pelayanan kesehatan sebesar 67,9\%. sedangkan sisanya yaitu sebesar 32,1\% dipengaruhi oleh variabel lain yang tidak terdapat dalam model penelitian. Seperti yang dinyatakan oleh Kementerian Kesehatan RI[4] faktor-faktor yang memengaruhi derajat kesehatan tidak hanya ekonomi, pendidikan, lingkungan, perilaku dan pelayanan kesehatan. Akan tetapi terdapat faktor lain yaitu: ketersediaan sarana dan prasarana kesehatan, lingkungan sosial, keturunan, dan kontribusi sektor yang terkait yang ikut memengaruhi derajat kesehatan masyarakat.

Pada tabel 1 dapat dijelaskan nilai koefisien jalur dan signifikansinya, yaitu: Nilai koefisien jalur hubungan ekonomi terhadap lingkungan sebesar $(0,110)$, menyatakan bahwa ekonomi tidak signifikan berpengaruh positif terhadap lingkungan. Nilai koefisien jalur hubungan ekonomi terhadap derajat kesehatan sebesar (-0,351) menyatakan bahwa kondisi ekonomi berpengaruh negatif terhadap derajat kesehatan. Nilai koefisien jalur hubungan pendidikan terhadap perilaku sebesar $(-0,029)$, menyatakan bahwa pendidikan tidak signifikan berpengaruh negatif terhadap perilaku. Nilai koefisien jalur hubungan pendidikan terhadap derajat kesehatan sebesar $(-0,321)$ menyatakan bahwa tingkat pendidikan berpengaruh negatif terhadap derajat kesehatan. Nilai koefisien jalur hubungan pelayanan kesehatan terhadap derajat kesehatan sebesar $(-0,176)$ menyatakan bahwa pelayanan kesehatan tidak signifikan berpengaruh negatif terhadap derajat kesehatan. Nilai koefisien jalur hubungan lingkungan terhadap derajat kesehatan sebesar $(-0,217)$ menyatakan bahwa lingkungan berpengaruh negatif terhadap derajat kesehatan. Nilai koefisien jalur hubungan perilaku terhadap derajat kesehatan sebesar $(0,305)$ menyatakan bahwa perilaku berpengaruh positif terhadap derajat kesehatan. Serta terdapat korelasi positif yang signifikan antara ekonomi dengan pendidikan sebesar 0,674. Berdasarkan hasil evaluasi model keseluruhan didapatkan nilai FIT sebesar 0,450 dan AFIT sebesar 0,429. Hal ini menunjukkan bahwa model belum cukup baik memperhatikan nilai FIT dan AFIT di bawah 0,5 dan hanya sekitar 45\% keragaman data dapat dijelaskan oleh model.

\section{Kesimpulan}

Semakin tinggi ekonomi, semakin tinggi tingkat pendidikan, dan semakin baik lingkungan akan menurunkan pengukur derajat kesehatan (AKB, kasus TB paru). Semakin meningkat pengukur perilaku sehat akan meningkatkan pengukur derajat kesehatan (AKB, kasus TB paru). Pengaruh ekonomi terhadap lingkungan, pendidikan terhadap perilaku dan pelayanan kesehatan terhadap derajat kesehatan menunjukkan hubungan tidak signifikan. Model yang dibangun dalam penelitian ini belum cukup baik memperhatikan nilai FIT dan AFIT di bawah 0,5 . Peneliti yang tertarik melanjutkan agar lebih mengkaji indikator yang 
digunakan dan disarankan memperhatikan adanya kemungkinan efek moderasi dan mediasi pada model struktural.

\section{Daftar Pustaka}

[1] Effendy, N., 1998. Dasar-Dasar Keperawatan Kesehatan Masyarakat. Jakarta: Kedokteran EGC.

[2] Ghozali, I., 2008. Generalized Structured Component Analysis (GSCA) Model Persamaan Structural Berbasis Komponen. Semarang: Penerbit Universitas Diponegoro.

[3] Hwang, H. \& Takane, Y., 2004. Generalized Structured Component Analysis. Psychometrika, 69(1), pp.81-99.

[4] Kementerian Kesehatan RI, 2011. Profil Kesehatan Indonesia Tahun 2010. Jakarta: Kementrian Kesehatan RI.

[5] Fornell, C. \& Larcker, D.F., 1981. Evaluating Structural Equation Models with Unobservable Variables and Measurement Error. Journal of Marketing Research, 18(1), pp.39-50. 